\title{
FORECASTING ECOLOGICAL IMPACTS OF SEA-LEVEL RISE ON COASTAL CONSERVATION AREAS IN INDIA
}

\section{Zafar-ul Islam ${ }^{1}$, Shaily Menon ${ }^{2}$, Xingong $\mathrm{Li}^{3} \&$ A. Townsend Peterson ${ }^{4}$}

${ }^{1}$ Bombay Natural History Society, Opp. Lion Gate, Shaheed Bhagat Singh Road, Mumbai, Maharashtra 400001, India

${ }^{1}$ Current Address: National Wildlife Research Center, PO Box 1086, Taif, Saudi Arabia

${ }^{2}$ Department of Biology, Grand Valley State University, Allendale, Michigan 49401 USA

OPEN ACCESS

${ }^{3}$ Department of Geography, University of Kansas, Lawrence, Kansas 66045 USA

${ }^{4}$ Biodiversity Institute, University of Kansas, Lawrence, Kansas 66045 USA

${ }^{1}$ mzafarul.islam@gmail.com (corresponding author), ${ }^{2}$ menons@gvsu.edu, ${ }^{3}$ lixi@ku.edu, ${ }^{4}$ town@ku.edu

\begin{abstract}
In addition to the mounting empirical data on direct implications of climate change for natural and human systems, evidence is increasing for indirect climate change phenomena such as sea-level rise. Rising sea levels and associated marine intrusion into terrestrial environments are predicted to be among the most serious eventual consequences of climate change. The many complex and interacting factors affecting sea levels create considerable uncertainty in sea-level rise projections: conservative estimates are on the order of 0.5-1.0 $\mathrm{m}$ globally, while other estimates are much higher, approaching $6 \mathrm{~m}$. Marine intrusion associated with 1-6 m sea-level rise will impact species and habitats in coastal ecosystems severely. Examining areas most vulnerable to such impacts may allow design of appropriate adaptation and mitigation strategies. We present an overview of potential effects of $1 \mathrm{~m}$ and $6 \mathrm{~m}$ sea level rise for coastal conservation areas in the Indian Subcontinent. In particular, we examine the projected magnitude of areal losses in relevant biogeographic zones, ecoregions, protected areas (PAs) and important bird areas (IBAs). In addition, we provide a more detailed and quantitative analysis of likely effects of marine intrusion on 22 coastal PAs and IBAs that provide critical habitat for birds in the form of breeding areas, migratory stopover sites and overwintering habitats. Several coastal PAs and IBAs are predicted to experience higher than $50 \%$ areal losses to marine intrusion. We explore consequences of such inundation levels for species and habitats in these areas.
\end{abstract}

Keywords: Adaptation, biogeographic zones, coastal inundation, ecoregions, important bird areas, marine intrusion, mitigation, protected areas, sea-level change.

DOI: http://dx.doi.org/10.11609/JoTT.03163.4349-58

Editor: S. Jayakumar, Pondicherry University, Puducherry, India.

Date of publication: 26 May 2013 (online \& print)

Manuscript details: Ms \# 03163 | Received 15 April 2012 | Final received 22 December 2012 | Finally accepted 18 April 2013

Citation: Islam, M.Z., S. Menon, X. Li \& A.T. Peterson (2013). Forecasting ecological impacts of sea-level rise on coastal conservation areas in India. Journal of Threatened Taxa 5(9): 4349-4358; http://dx.doi.org/10.11609/JoTT.o3163.4349-58

Copyright: ( Islam et al. 2013. Creative Commons Attribution 3.0 Unported License. JoTT allows unrestricted use of this article in any medium, reproduction and distribution by providing adequate credit to the authors and the source of publication.

Funding: None.

Competing Interest: None.

Acknowledgements: We gratefully acknowledge the suggestion and encouragement from Dr. Asad Rahmani (Director, BNHS) to conduct this analysis and the feedback from two anonymous reviewers which improved the manuscript. We are grateful to HH Prince Bandar bin Mohammad Saud Al Saud (President of SWA) and Mr. Ahmed Boug (General Director, NWRC).

Author Details: DR. M. ZAFAR-UL ISLAM is an ecologist with strong interest in international wildlife conservation. His main research is on ecology and biology of globally threatened species of birds and mammals and the geography and ecology of species' distributions and climate change. He has published 13 books mainly with OUP-BNHS and around 100 scientific papers/articles. Worked with the BNHS-India for 15 years and presently with the National Wildlife Research Center since April 2006 as Research Coordinator in Saudi Arabia. DR. SHAILY MENON is an Associate Dean in the College of Liberal Arts and Sciences and a Professor of Biology and Natural Resources Management at Grand Valley State University in Michigan. Her research is in the areas of conservation biology, biodiversity informatics, and examining the effects of land, sea, and climate change on species and habitats. DR. XINGONG LI is an Associate Professor of Geography at the University of Kansas. His primary research interest is in the development of spatial analysis methods and tools to understand hydrological processes and the interaction between human and water. Prof. A. TOWNSEND PETERSON is University Distinguished Professor of Ecology and Evolutionary Biology at the University of Kansas. His primary research interests lie in the geography and evolution of world birds, geographic aspects of disease transmission risk, and the geography and ecology of species' distributions.

Author Contribution: MZI collected data, analysis and paper writing in association with other authors. SM contributed to data analysis, writing the manuscript, and compiling the figures for the manuscript. XL contributed to data analysis, specifically, the delineation of inundated areas by different sea level rises. ATP assisted with study design and with writing the manuscript.
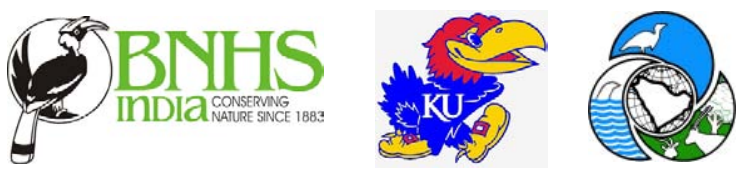


\section{INTRODUCTION}

Several recent studies have accumulated empirical evidence of climate change effects on the distribution and diversity of species and ecosystems. Examples include poleward and upward elevational range shifts in butterfly (Parmesan et al. 1999; Parmesan \& Yohe 2003) and mammal species (Moritz et al. 2008; Tingley et al. 2009), mistimed reproduction in bird species (Visser et al. 1998) and advanced spring greenup and other changes in plant phenology (Miller-Rushing \& Primack 2008; Vitasse et al. 2009). Such empirical evidence is complemented by predictive modeling efforts based on linkage of ecological niche models with general circulation model (GCM) outputs (e.g., Erasmus et al. 2002; Peterson et al. 2002, 2005; Thomas et al. 2004a; Araújo et al. 2005; Anciães \& Peterson 2006), which anticipate similar poleward and upward shifts, with significant range losses when species' dispersal potential is constrained by geographic factors.

Indirect climate change-associated phenomena such as sea-level rise are also beginning to receive attention. Major causes of rising sea levels include thermal expansion of the ocean, mountain glacier melting, and discharge ice from ice sheets (Dyurgerov \& Meier 1997). Accelerating discharge of glacial ice due to ice sheet melt and tidal and storm surges are expected to exacerbate the situation further. Projections of sealevel rise can vary dramatically owing, at least in part, to the complexity of the factors contributing to this phenomenon. Carter et al. (2007) and IPCC (2007) offered a conservative estimate of anticipated sea-level rise on the order of $0.5-1.0 \mathrm{~m}$, while other estimates are much higher on the order of 4-6 m (Bindschadler 1998; Thomas et al. 2004b; Rignot \& Kanagaratnam 2006).

Rising sea levels and associated marine intrusion into terrestrial environments are expected to be among the most serious consequences of climate change. Projected estimates of 1-6 $\mathrm{m}$ rise of sea levels are likely to have catastrophic consequences for biodiversity and humans. The human and economic consequences of sea-level rise have received some attention in recent years (Titus 1990; Mimura 1999; Hitz \& Smith 2004; Bosello et al. 2007). A few analyses have addressed various aspects of the biodiversity consequences of sea-level change: threatened and endangered species' habitat destruction in the southeastern US (Daniels et al. 1993), potential losses of intertidal habitat for shorebirds (Galbraith et al. 2001), potential effects in a mangrove ecosystem (Gopal \& Chauhan 2006), likely effects on a single endangered species (LaFever et al. 2007) and ecosystem adaptation to rising sea levels (McKee et al. 2007).

A first-pass global assessment of biodiversity consequences of the sea-level rise (Menon et al. 2010), provided rough estimates of areal losses of ecoregions and species extinctions due to marine intrusion: several ecoregions were projected to lose more than half of their present-day land area even under a $1 \mathrm{~m}$ sea-level rise. Recent events, such as the disappearance of New Moore Island in the Bay of Bengal (BBC News 2010) have further underscored the urgency of this issue. Acknowledging the significance of this topic, the Survey of India announced, in March 2010, a plan to map the hazard line along India's coastlines.

Here, we present an overview of potential consequences of $1 \mathrm{~m}$ and $6 \mathrm{~m}$ sea-level rise for coastal conservation areas on the Indian subcontinent. Specific objectives of this study were to explore (i) areal losses due to marine intrusion in coastal biogeographic zones and ecoregions; (ii) likely impacts of marine intrusion on coastal protected areas (PAs) and Important Bird Areas (IBAs), which provide critical habitat for species; and (iii) adaptation and mitigation strategies for minimizing such impacts.

\section{METHODS}

\section{Data Sources}

We used the output of the study generated by Li et al. (2009). This method implemented several steps in a GIS raster analysis framework to select and designate as 'inundated areas' those cells that (i) are below a projected sea level rise, (ii) are connected to the ocean, and (iii) are not part of existing inland water bodies. The sea-level rise scenarios generated by this method are an improvement on previous estimates (Dasgupta et al. 2007; LaFever et al. 2007) which tended to overpredict potential inundated areas.

GIS data sets of conservation areas were obtained from various sources. Biogeographic zones (areas with shared biological and geographic characteristics) were delineated from maps prepared by Rodgers \& Panwar (1988) and Rodgers et al. (2002). Ecoregion data were obtained from the Terrestrial Ecoregions GIS Database (Olson et al. 2001). Protected areas maps were obtained from the World Database on Protected Areas (IUCN and UNEP-WCMC 2010). Finally, point location data for conservation areas were obtained from field surveys, published records and cross-checked with gazetteers of India (Islam \& Rahmani 2004; Islam \& Rahmani 2008). 


\section{Estimates of areal loss and biodiversity impacts}

We converted the GIS layers of biogeographic zones, ecoregions and protected areas into equal-area grids (we used Albers projection because it preserves area measurements). After assuring that all grids were on a common projection and grid resolution, we estimated areal loss resulting from marine intrusion by overlaying them with the $1 \mathrm{~m}$ and $6 \mathrm{~m}$ inundation grids. Gridsquare resolution was $822 \mathrm{~m}$ on a side. Data on globally threatened birds were collected from field surveys, published records, BirdLife International, and Indian Bird Conservation Network (IBCN) partners, and were validated by comparison with summaries from regional IBA workshops across the country in 2001 and 2002 (Islam \& Rahmani 2004). Digital data on biogeographic zones were obtained from BirdLife International (1998), Rodgers \& Panwar (1988), Rodgers et al. (2000), and Champion \& Seth (1968).

\section{RESULTS}

Total areal loss due to marine intrusion into coastal areas of the Indian subcontinent is estimated at approximately $13,973 \mathrm{~km}^{2}(3 \%)$ and $60,497 \mathrm{~km}^{2}$ $(14 \%)$ of the land area under the $1 \mathrm{~m}$ and $6 \mathrm{~m}$ sea-level rise scenarios, respectively (Table 1 ). Inundation of biogeographic zones ranged from $0-18 \%$ under $1 \mathrm{~m}$ sea-level rise and $0-56 \%$ under $6 \mathrm{~m}$ sea-level rise. As

Table 1. Predicted inundation of biogeographic zones of India by marine intrusion as a result of $1 \mathrm{~m}$ and $6 \mathrm{~m}$ sea-level rise.

\begin{tabular}{|l|c|c|c|c|c|}
\hline \multirow{2}{*}{$\begin{array}{l}\text { Biogeographic } \\
\text { Zone* }\end{array}$} & \multirow{2}{*}{$\begin{array}{c}\text { Total } \\
\text { area }\end{array}$} & \multicolumn{4}{|c|}{ Area inundated } \\
\cline { 3 - 6 } & & \multicolumn{2}{|c|}{$1 \mathrm{~m}$ sea-level rise } & $6 \mathrm{~m}$ sea-level rise \\
\hline & $\mathrm{km}^{2}$ & $\mathrm{~km}^{2}$ & $\%$ & $\mathrm{~km}^{2}$ & $\%$ \\
\hline Coasts & 103,747 & 12,631 & 12.2 & 58,282 & 56.2 \\
\hline Desert & 197,480 & 32 & 0 & 191 & 0.1 \\
\hline Western Ghats & 132,141 & 73 & 0.1 & 419 & 0.3 \\
\hline Islands & 7,058 & 1237 & 17.5 & 1605 & 22.7 \\
\hline TOTAL & 440,426 & 13,973 & 3.2 & 60,497 & 13.7 \\
\hline
\end{tabular}

* Source: Rodgers \& Panwar (1988), Rodgers et al. (2000), Islam \& Rahmani 2004

Table 2. Predicted inundation of coastal ecoregions by marine intrusion as a result of $1 \mathrm{~m}$ and $6 \mathrm{~m}$ sea-level rise.

\begin{tabular}{|c|c|c|c|c|c|}
\hline Ecoregion* & $\begin{array}{l}\text { Total Area } \\
\left(\mathrm{km}^{2}\right)^{*}\end{array}$ & $\begin{array}{l}\text { Area inundated } \\
\text { by } 1 \mathrm{~m} \text { sea-level } \\
\text { rise }\left(\mathrm{km}^{2}\right)\end{array}$ & $\begin{array}{l}\text { \% inundated by } \\
1 \mathrm{~m} \text { sea-level rise }\end{array}$ & $\begin{array}{c}\text { Area inundated } \\
\text { by } 6 \mathrm{~m} \text { sea-level } \\
\text { rise }\left(\mathrm{km}^{2}\right)\end{array}$ & $\begin{array}{l}\text { \% inundated by } \\
6 \mathrm{~m} \text { sea-level rise }\end{array}$ \\
\hline Northwestern thorn scrub forests & 243,569 & 383 & 0.2 & 4,692 & 1.9 \\
\hline Khathiar-Gir dry deciduous forests & 265,936 & 0 & 0.0 & 1,093 & 0.4 \\
\hline Lower Gangetic Plains moist deciduous forests & 145,758 & 0 & 0.0 & 4,262 & 2.9 \\
\hline Rann of Kutch seasonal salt marsh & 24,215 & 172 & 0.7 & 14,033 & 58.0 \\
\hline Eastern highlands moist deciduous forests & 340,058 & 1,167 & 0.3 & 3,143 & 0.9 \\
\hline Sundarbans freshwater swamp forests & 6,862 & 140 & 2.0 & 2,985 & 43.5 \\
\hline Sundarbans mangroves & 4,294 & 2,510 & 58.5 & 3,100 & 72.2 \\
\hline Indus River Delta-Arabian Sea mangroves & 1,922 & 57 & 3.0 & 356 & 18.5 \\
\hline Deccan thorn scrub forests & 336,091 & 0 & 0.0 & 2,195 & 0.7 \\
\hline North Western Ghats moist deciduous forests & 48,049 & 0 & 0.0 & 80 & 0.2 \\
\hline Central Deccan Plateau dry deciduous forests & 239,352 & 0 & 0.0 & 1,545 & 0.7 \\
\hline Orissa semi-evergreen forests & 21,321 & 1,539 & 7.2 & 4,229 & 19.8 \\
\hline Goadavari-Krishna mangroves & 6,066 & 2,147 & 35.4 & 4,239 & 69.9 \\
\hline Malabar Coast moist forests & 34,154 & 1,077 & 3.2 & 4,669 & 13.7 \\
\hline East Deccan dry-evergreen forests & 25,087 & 1,876 & 7.5 & 6,043 & 24.1 \\
\hline Andaman Islands rain forests & 4,817 & 1,122 & 23.3 & 1,545 & 32.1 \\
\hline $\begin{array}{l}\text { Maldives-Lakshadweep-Chagos Archipelago Tropical Moist } \\
\text { Forest }\end{array}$ & 26 & 5 & 21.1 & 7 & 26.3 \\
\hline Nicobar Islands rain forests & 1,424 & 87 & 6.1 & 118 & 8.3 \\
\hline Total & & 12,282 & & 58,334 & \\
\hline
\end{tabular}

* Source: Rodgers \& Panwar (1988), Rodgers et al. (2000), Islam \& Rahmani 2004 
expected, "Coasts" and "Islands" are the zones predicted to be most severely impacted by potential marine intrusion. "Coasts" are predicted to undergo $12 \%$ and $56 \%$ inundation under the two sea-level rise projections, and "Islands" are predicted to undergo 18\% and 23\% inundation (Table 1).

Marine intrusion is predicted to affect 18 of the 48 ecoregions in India (Table 2). Under the $1 \mathrm{~m}$ sea-level rise scenario, estimates of ecoregion inundation ranged from $19 \%$ to $59 \%$. Under the $6 \mathrm{~m}$ sea-level rise scenario, estimates of ecoregion inundation ranged from 27-58 $\%$ (Table 2). Under the $1 \mathrm{~m}$ sea-level rise scenario, one ecoregion (Godavari-Krishna mangroves) is predicted to lose more than a quarter of its area and another
(Sunderbans mangroves) is predicted to lose more than half of its area. Under the $6 \mathrm{~m}$ sea-level rise scenario, three ecoregions (Sunderbans freshwater swamp forests, Andaman Islands rain forests, and MaldivesLakshadweep-Chagos Archipelago tropical moist forest) are predicted to lose more than a quarter of their land areas, and three more (Sunderbans mangroves, Godavari-Krishna mangroves, and Rann of Kutch seasonal salt marsh) are predicted to lose more than half of their land area.

An overlay of point locations of IBAs indicates that 12 IBAs (Austin Strait, Baratang-Rafter's Creek, Bhitarakanika, Chilka Lake, Coringa and Godavari Estuary, Interview Island, Kattampally, Point Calimere, Pulicat

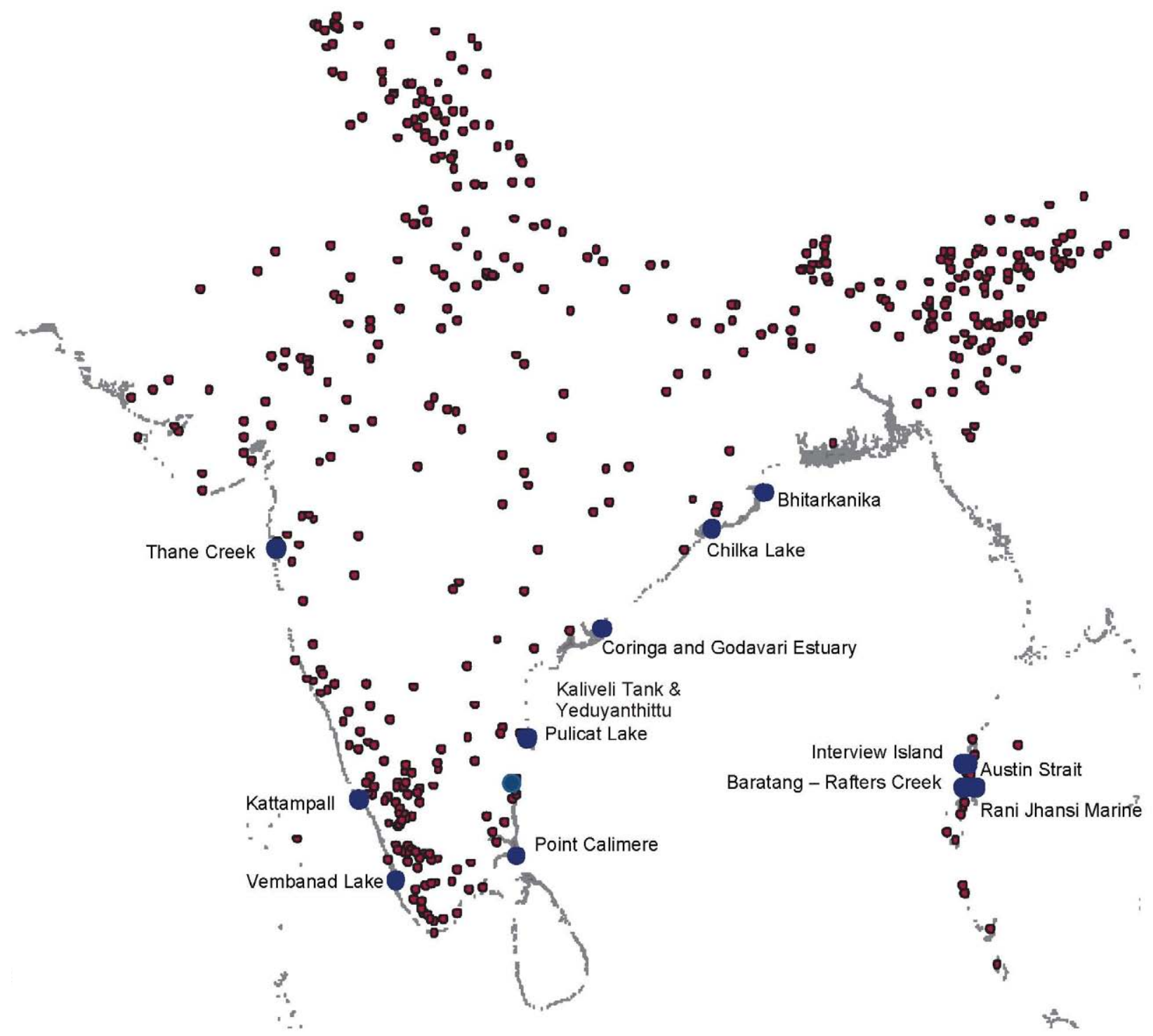

Figure 1a. Important Bird Areas (IBAs) directly affected by a 1m sea-level rise, shown as solid blue circles. Other IBAs are shown as red circles and inundated areas appear in gray. 
Lake, Rani Jhansi Marine, Thane Creek, and Vembanad Lake) are likely to be impacted to some degree by $1 \mathrm{~m}$ sea-level rise; an additional 12 (Banni Grassland and Chhari Dhand, Big Tank and Sakkarakotai Kanmal, Chainpur and Hanspuri, Flamingo City, Kole, Land Fall Island, Mahul-Sewri Mudflats, Sundarban, Tilanghong, Vaduvoor, Velavadar Blackbuck Sanctuary, and Wildass and Nanda Island) are likely to be impacted by $6 \mathrm{~m}$ sealevel rise. Areal estimates are not possible for IBAs for lack of detailed maps of their boundaries (Fig. 1a \& b).

A closer examination of a sample of 22 coastal conservation areas (Table 3 ) indicates that nine will be spared effects of marine intrusion under $1 \mathrm{~m}$ sea-level rise, but only one will be spared under a $6 \mathrm{~m}$ sea-level rise scenario. Of those impacted by marine intrusion, the extent of predicted inundation is quite variable, ranging from $1-95 \%$ and $2-100 \%$ under $1 \mathrm{~m}$ and $6 \mathrm{~m}$ sealevel rise, respectively (Table 3 ). Seven protected areas (Bhitarkanika, Chilka Lake, Point Calimere, Interview Island, Lothian Island, Sajnakhali, and Pulicat Lake) are expected to experience $>50 \%$ inundation under $1 \mathrm{~m}$ sea-level rise, and an additional four protected areas (Kachchh Desert, Velavadar, Pulicat, and Nal Sarovar), join this list under $6 \mathrm{~m}$ sea-level rise. Images 1-4 depict the extent of predicted marine intrusion in some of these protected areas and their surroundings.

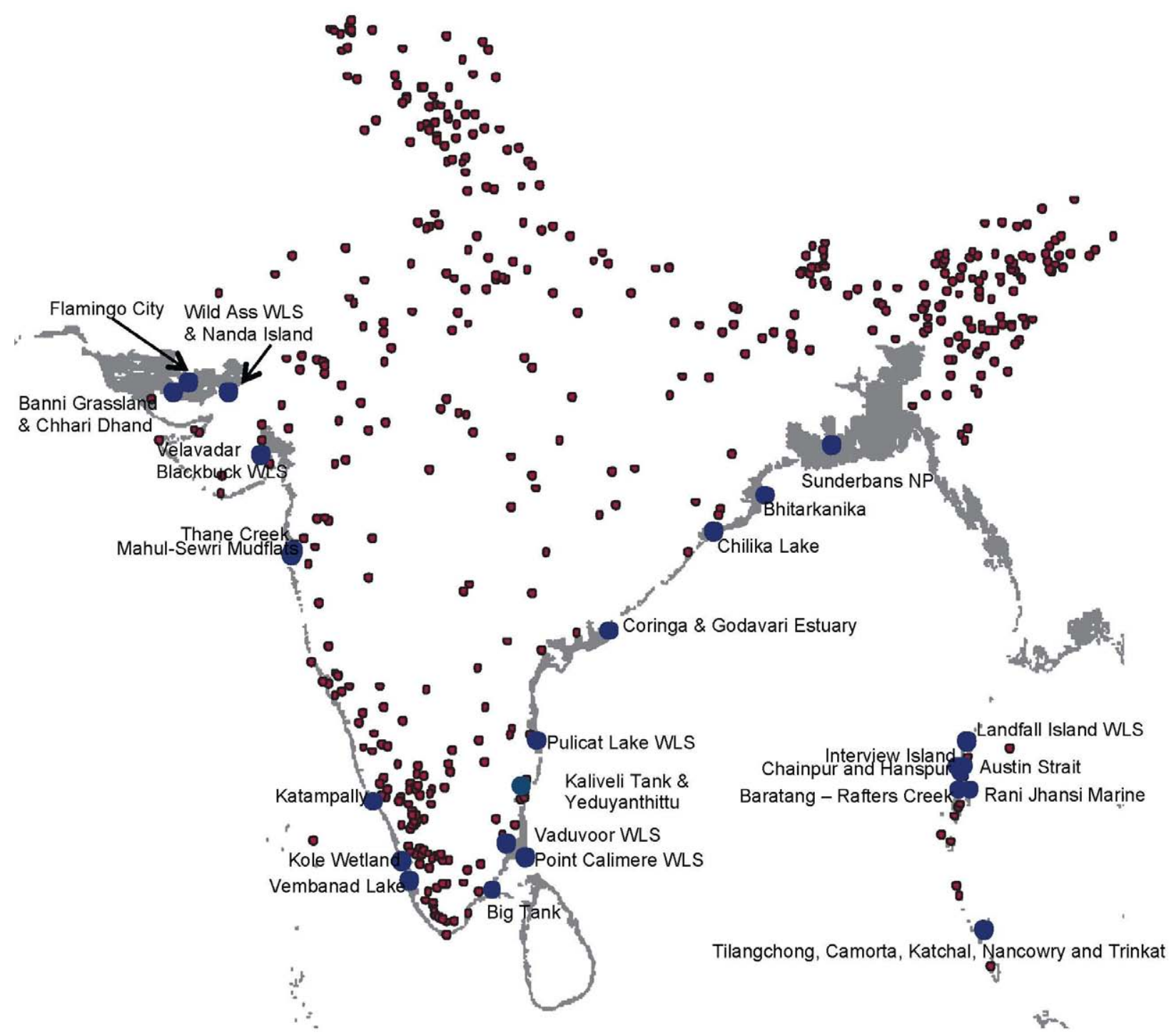

Figure 1b. Important Bird Areas (IBAs) directly affected by $6 \mathrm{~m}$ sea-level rise, shown as solid blue circles. Other IBAs are shown as red circles and inundated areas appear in gray. 
Table 3. Extent of selected conservation areas (PAs and IBAs) inundated by marine intrusion as a result of $1 \mathrm{~m}$ and $6 \mathrm{~m}$ sea-level rise.

\begin{tabular}{|l|c|c|c|c|c|}
\hline \multirow{2}{*}{$\begin{array}{l}\text { Protected Areas \& } \\
\text { IBAs* }\end{array}$} & \multirow{2}{*}{ Total Area } & \multicolumn{4}{|c|}{ Area Inundated } \\
\cline { 3 - 6 } & & $\mathbf{1}$ rea-level & 6m sea-level rise \\
\hline & $\mathbf{k m}^{2}$ & $\mathbf{k m}^{\mathbf{2}}$ & $\%$ & $\mathbf{k m}^{2}$ & $\%$ \\
\hline Battimalv Island & 5 & 1 & 20 & 1 & 20 \\
\hline Bhitarkanika & 41 & 39 & 95.1 & 41 & 100 \\
\hline Campbell & 345 & 1 & 0.2 & 1 & 0.4 \\
\hline Chilika Lake & 984 & 766 & 77.8 & 782 & 79.5 \\
\hline Coringa & 137 & 40 & 29 & 40 & 29 \\
\hline Gulf of Kutch & 826 & 34 & 4.1 & 73 & 8.8 \\
\hline Gulf of Mannar & 376 & 1 & 0.2 & 7 & 1.8 \\
\hline Haliday Island & 4 & 0 & 0 & 1 & 33.3 \\
\hline Interview Island & 133.87 & 96 & 71.7 & 105 & 78.4 \\
\hline Kachchh Desert & 13,577 & 135 & 1.0 & 11,691 & 86.1 \\
\hline Lothian Island & 24 & 16 & 66.6 & 16 & 66.6 \\
\hline Nal Sarovar & 49 & 0 & 0 & 28 & 56.2 \\
\hline Narayan Sarovar & 833 & 4 & 0.5 & 84 & 10.1 \\
\hline Narendrapur & 201 & 0 & 0 & 39 & 19.5 \\
\hline Nellapattu & 134 & 0 & 0 & 16 & 11.6 \\
\hline Point Calimere & 377.33 & 293 & 77.5 & 370 & 98.1 \\
\hline Pulicat & 117 & 24 & 20.8 & 72 & 61.3 \\
\hline Pulicat Lake & 526 & 284 & 53.9 & 374 & 71 \\
\hline Sajnakhali & 2,091 & 1,209 & 57.8 & 1,300 & 62.2 \\
\hline Tillongchang Island & 32 & 5 & 14.9 & 8 & 25.5 \\
\hline Velavadar & 45 & 0 & 0 & 33 & 74.2 \\
\hline Wild Ass & 765 & 0 & 0 & 1,342 & 18.7 \\
\hline & & & & & \\
\hline
\end{tabular}

* Source: Rodgers \& Panwar (1988), Rodgers et al. (2000), Islam \& Rahmani 2004

\section{DISCUSSION}

As in the preliminary assessment of global areal losses of ecoregions (Menon et al. 2010), the increased losses under the $6 \mathrm{~m}$ scenario is clear in this analysis. Several coastal ecoregions and conservation areas are predicted to lose over half of their land areas to marine intrusion, particularly under the $6 \mathrm{~m}$ sea-level rise scenario. Coastal zones have high biological productivity and support large number of birds and other taxa including mangroves. Populations of several species are expected to be displaced as a result of changes in the timing and magnitude of coastal biological productivity due to climate change (Both et al. 2006).

Most IBAs in coastal areas support species of global conservation concern, including some endemic and several breeding populations of threatened species.
Coastal IBAs in the Indian subcontinent support significant populations of globally threatened birds such as Spotbilled Pelican (Pelecanus philippensis), Oriental Whitebacked Vulture (Gyps bengalensis), and Greater Spotted Eagle (Aquila clanga) in Coringa, Godaveri, and Pulicat Lake estuaries on the coast of Andhra Pradesh, and large congregations of Spot-billed Pelican, Painted Stork (Mycteria leucocephala), Darter (Anhinga melanogaster), and Oriental White Ibis (Threskiornis melanocephalus) at Gulf of Mannar Marine National Park, Big Tank, Point Calimere Wildlife Sanctuary, Suchindram, Theroor, Vembanoor, Kaliveli Tank \& Yedayanthittu Estuary in Tamil Nadu and Bay of Bengal.

Sites on the western coast, such as Kattampally and Kole wetlands in Kerala, support large numbers of Spotbilled Pelican, Greater Spotted Eagle, Darter, Painted Stork, and Black-bellied Terns (Sterna acuticauda). Sites in Gujarat such as Chhari Dhand, Banni, Charakla Saltworks, Flamingo City, Kaj Lake, Khijadiya coastal Lake, Marine National Park, Nal Saorvar Sanctuary, Salt Pans of Bhavnagar, Wild Ass Sanctuary, and Nanda Island support large numbers of coastal and wetland birds, including large populations of Lesser and Greater flamingos (Phoenicopterus minor, P. roseus), Common and Demoiselle Cranes (Grus grus and G. virgo), Greater White Pelican (Pelecanus onocrotalus), Black-tailed Godwit (Limosa limosa), Painted Stork, Black-necked Stork (Ephippiorhynchus asiaticus), Indian Skimmer (Rynchops albicollis), and Dalmatian Pelican (Pelecanus crispus). In Maharashtra, sites such as Burnt Island, Sewree-Mahul mudflats, and Thane Creek support large congregations of flamingos and waders.

The Andaman Islands support eight endemic bird species, and an additional four restricted-range species that they share with the Nicobar Islands. One endemic species, the Narcondam Hornbill (Aceros narcondami), is globally threatened and confined to the tiny island of Narcondam $\left(<7 \mathrm{~km}^{2}\right)$ in the northern part of the island group. The status of Narcondam Hornbill needs to be assessed quickly, given the very small size of the island and its potential vulnerability. In addition, Andaman Teal (Anas albogularis), endemic to the Andamans, is scarce, has recently declined, and is likely to be affected by sealevel rise because of its coastal distribution.

Similarly five bird species are endemic to the Nicobar Islands. Three of the endemic species are globally threatened: Nicobar Sparrowhawk (Accipiter butleri), Nicobar Megapode (Megapodius nicobariensis) and Nicobar Bulbul (Hypsipetes nicobariensis); of these, Nicobar Megapode is of particular concern because its greatest concentrations are found in coastal forests. 

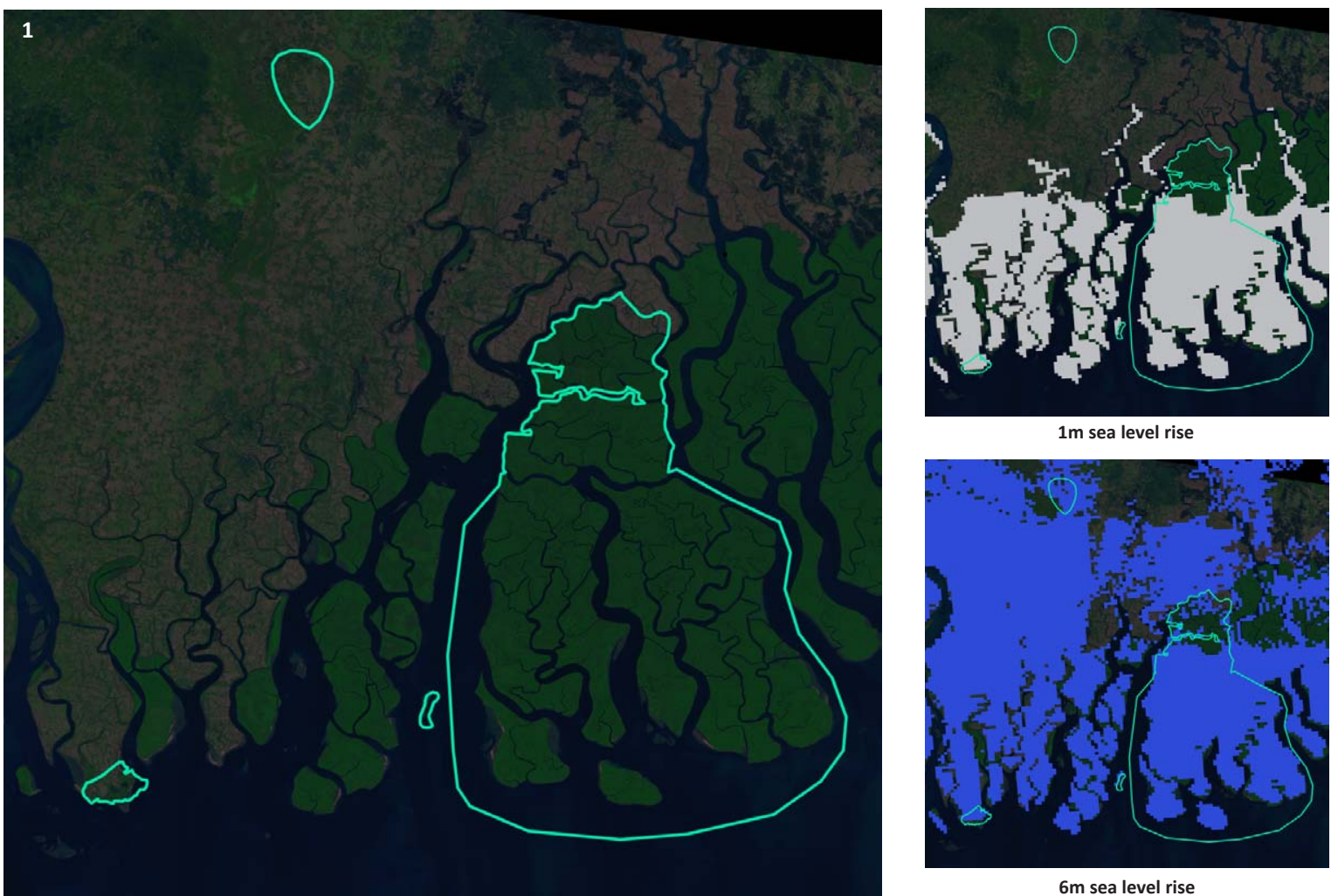

$1 \mathrm{~m}$ sea level rise

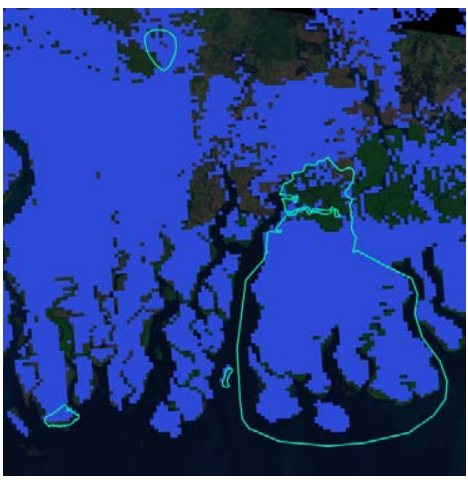

$6 \mathrm{~m}$ sea level rise
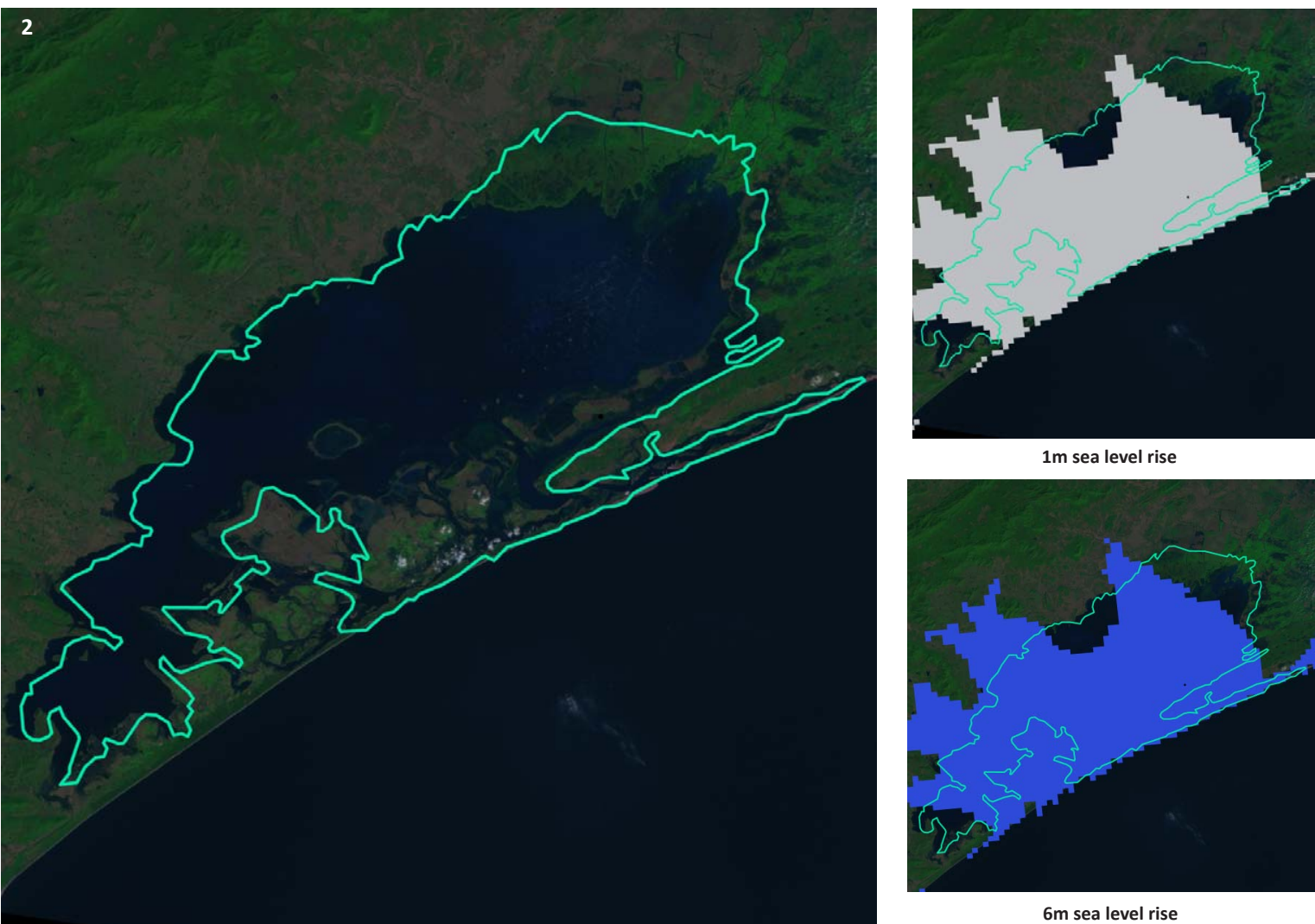

$1 \mathrm{~m}$ sea level rise

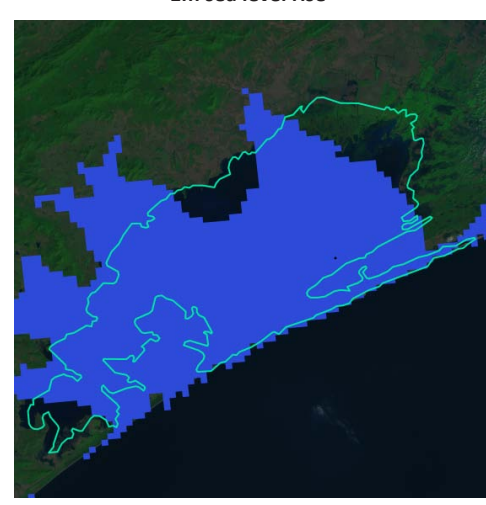

$6 \mathrm{~m}$ sea level rise

Images 1 \& 2. Selected conservation areas (protected areas and IBAs) impacted by sea-level rise (1) Haliday Island, Lothian Island, Narendrapur, and Sajnakhali Wildlife Sanctuary, (2) Chilka Lake [Key: These are true color satellite images, in which green represents vegetation, brown represents bare ground and dark blue is water. In the insets, the area inundated by $1 \mathrm{~m}$ sea level rise is indicated in white and the area inundated by $6 \mathrm{~m}$ sea level rise is shown in light blue.] 

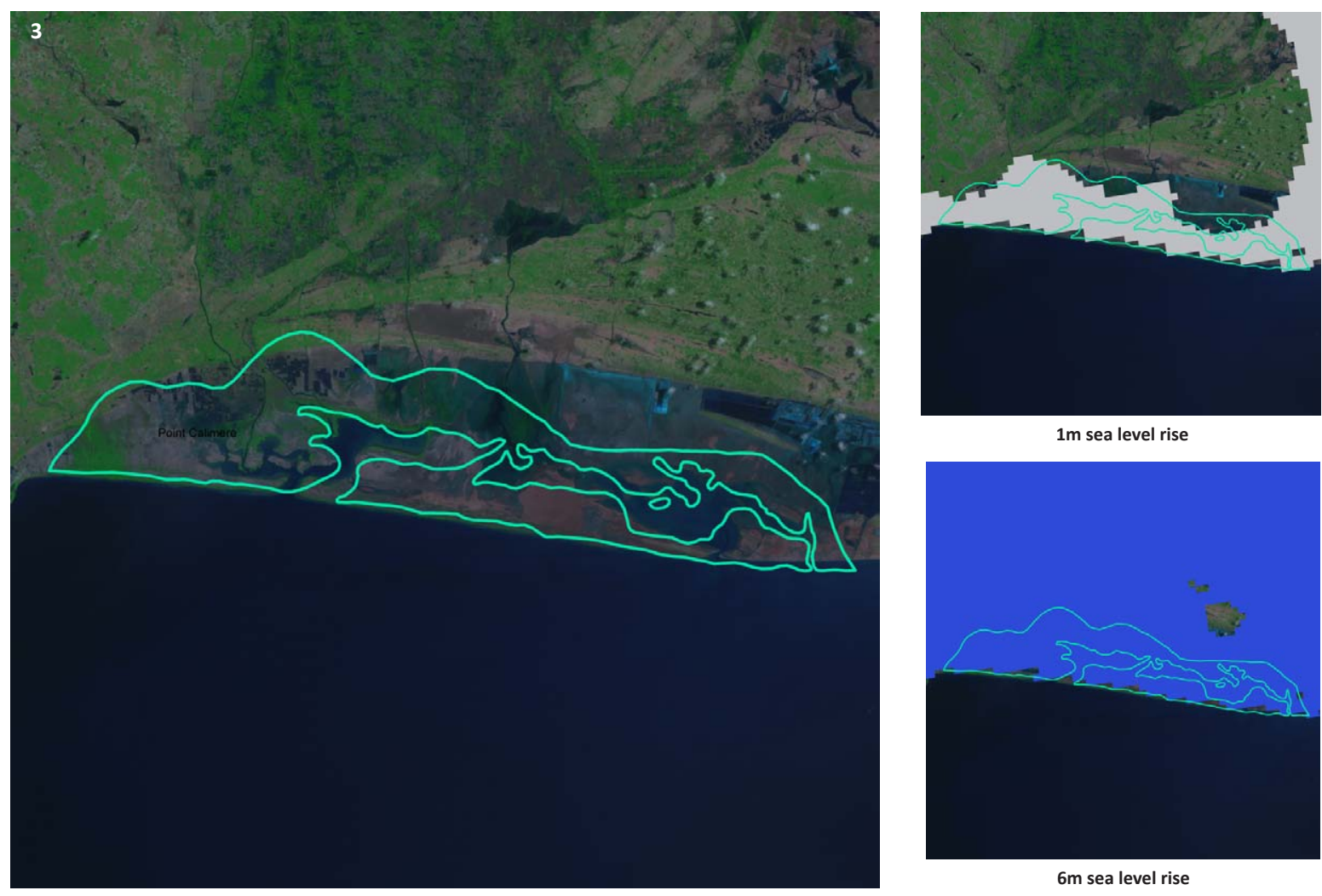

$1 \mathrm{~m}$ sea level rise

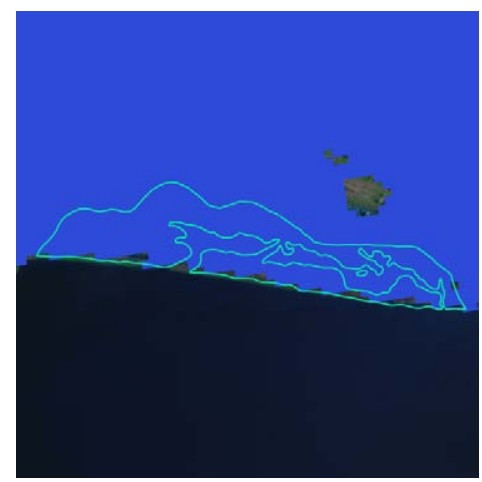

$6 \mathrm{~m}$ sea level rise
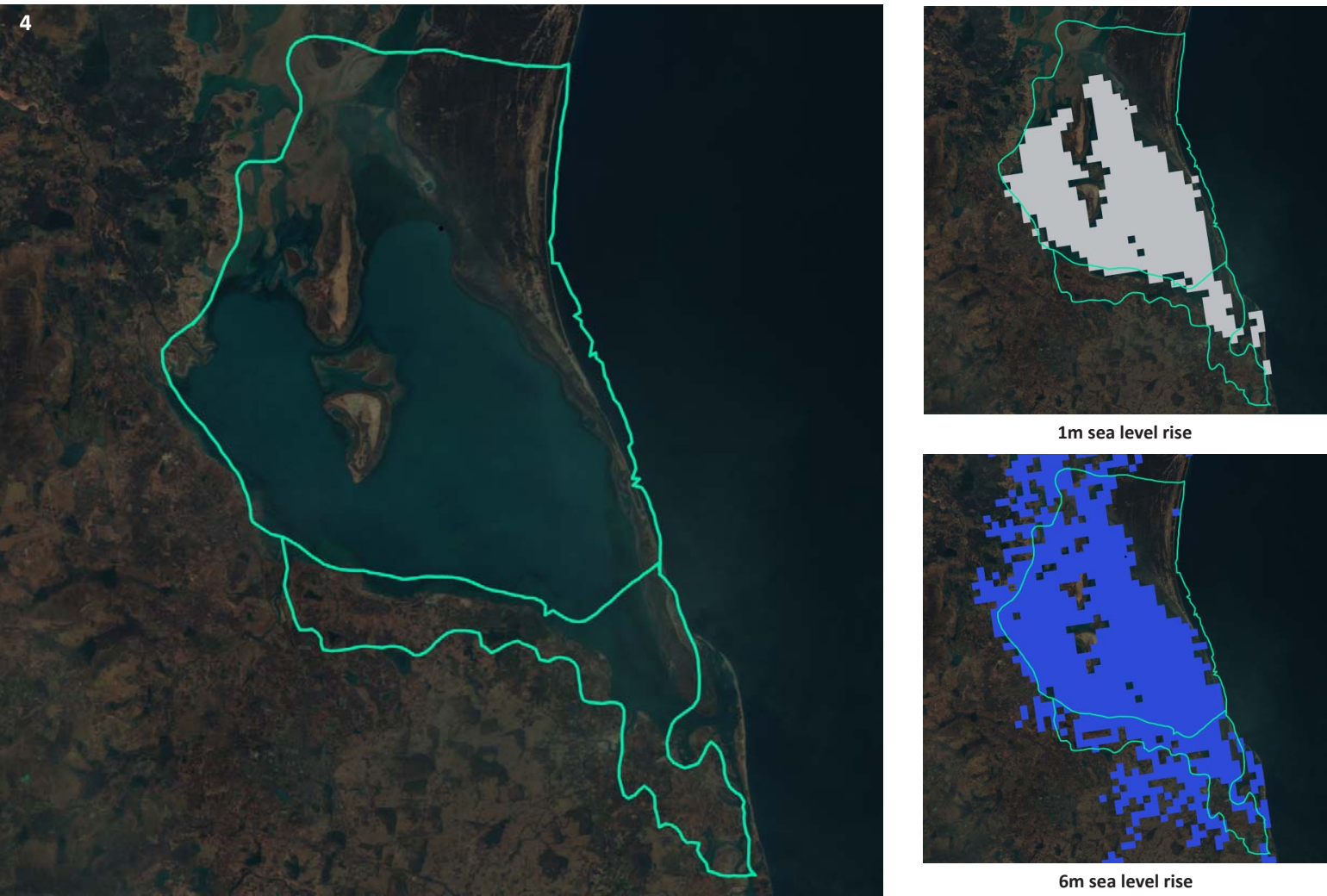

$1 \mathrm{~m}$ sea level rise

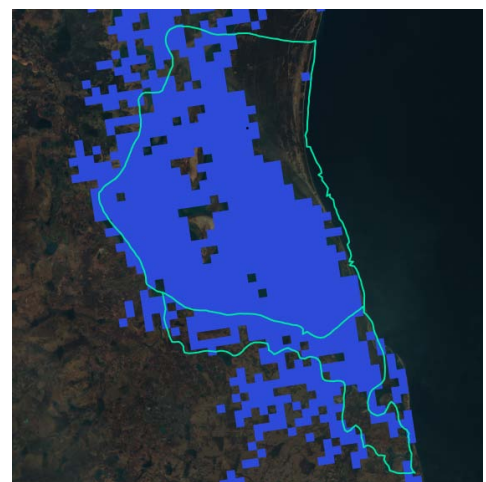

$6 \mathrm{~m}$ sea level rise

Images 3 \& 4. Selected conservation areas (protected areas and IBAs) impacted by sea-level rise (3) Point Calimere, and (4) Pulicat Lake and Pulicat Sanctuary. [Key: These are true color satellite images, in which green represents vegetation, brown represents bare ground and dark blue is water. In the insets, the area inundated by $1 \mathrm{~m}$ sea level rise is indicated in white and the area inundated by $6 \mathrm{~m}$ sea level rise is shown in light blue.] 
The other two endemic species, South Nicobar Serpenteagle (Spilornis klossi) and Nicobar Parakeet (Psittacula caniceps) are both Near Threatened and confined to the southern islands, and might also be affected.

The following globally threatened waterbird species occur in coastal wetlands likely to be affected by sea-level rise-Spot-billed Pelican (Pelecanus philippensis), Milky Stork (Mycteria cinerea), Lesser Adjutant (Leptoptilos javanicus), Spotted Greenshank (Tringa guttifer), Spoon-billed Sandpiper (Eurynorhynchus pygmeus) and Indian Skimmer (Rynchops albicollis). Three threatened waterbirds, Storm's Stork (Ciconia stormi), White-winged Duck (Cairina scutulata) and Masked Finfoot (Heliopais personata), occur in swamp forests and sometimes mangroves including coastal localities, and therefore may be impacted by sea-level rise, as are two threatened seabirds that occur in the Indian Ocean: Abbott's Booby (Papasula abbotti) and Christmas Island Frigatebird (Fregata andrewsi).

Hundreds of species of flora and fauna, including globally threatened species, depend upon low-lying coastal ecosystems for their survival. Indeed estuarine habitats and mudflats are sensitive to changes in both their upstream watersheds and the off-lying oceans. Several important biodiversity areas including in particular protected and non-protected IBAs in the Bay of Bengal and Arabian Sea, have already been stressed by numerous anthropogenic impacts as well as by invasive species (Islam \& Rahmani 2004; Islam \& Rahmani 2008), perhaps making them less resilient to change from the outset.

Coastal areas are subject to a range of intrinsic and extrinsic factors that could inhibit the ability of populations to adapt to climate change (Crick 2004). The prediction of future coastal evolution is hindered by the lack of standard methodology or agreement about the types of data and approaches required (Boesch et al. 2000). Factors that may impede tracking coastal changes include anthropogenic transformations, disjunct potential areas for species migration, and barriers to dispersal; where possible, ecosystems may respond by shifting inland, rather than with losses.

However, we note that protected areas, which generally have legal descriptions as part of their decrees, do not shift so easily, which may leave coastal areas inundated and key habitats unprotected. The inundation of mangroves is likely to result in a shift in species composition, with the deepest mangroves dying out. The methods used in our analyses are clear and quantitative with explicit assumptions. The relative susceptibility of different coastal environments to sea- level rise may be quantified at regional to national scales (Gornitz et al. 1994) using basic data on coastal geomorphology, rate of sea-level rise, and past shoreline evolution. More detailed coastal and marine geological data is needed to permit a comprehensive assessment of the susceptibility of the Indian subcontinent to sealevel rise.

\section{REFERENCES}

Anciães, M., \& A.T. Peterson (2006). Climate change effects on Neotropical manakin diversity based on ecological niche modeling. Condor 108: 778-791; http://dx.doi.org/10.1650/00105422(2006)108[778:CCEONM]2.0.CO;2

Araújo, M.B., R.G. Pearson, W. Thuiller \& M. Erhard (2005). Validation of species-climate impact models under climate change. Global Change Biology 11: 1504-1513; http://dx.doi.org/10.1111/j.13652486.2005.01000.x

BBC News (2010). Disputed Bay of Bengal island 'vanishes' say scientists. Available at: http://news.bbc.co.uk/2/hi/8584665.stm [Accessed on 27 January 2012].

Bindschadler, R.A. (1998). Future of the West Antarctic Ice Sheet. Science 282: 428-429.

BirdLife International (1998). Important Bird Areas (IBAs) in Asia: Project Briefing Book. BirdLife International, Cambridge, U.K.

Boesch, D.F., J.C. Field \& D. Scavia (eds.) (2000). The Potential Consequences of Climate Variability and Change on Coastal Areas and Marine Resources: Report of the Coastal Areas and Marine Resources Sector Team, U.S. National Assessment of the Potential Consequences of Climate Variability and Change, U.S. Global Change Research Program. NOAA Coastal Ocean Program Decision Analysis Series No. \# 21. NOAA Coastal Ocean Program, Silver Spring, MD.

Both C., S. Bouwhuis, C.M. Lessells \& M.E. Visser (2006). Climate change and population declines in a long-distance migratory bird. Nature 441: 81-83; http://dx.doi.org/10.1038/nature04539

Bosello, F., R. Roson \& R. Tol (2007). Economy-wide estimates of the implications of climate change: Sea level rise. Environmental and Resource Economics 37: 549-571; http://dx.doi.org/10.1007/ s10640-006-9048-5

Carter, T.R., R.N. Jones, X. Lu, S. Bhadwal, C. Conde, L.O. Mearns, B.C. O'Neill, M.D.A. Rounsevell \& M.B. Zurek (2007). New assessment methods and the characterization of future conditions, pp. 133171. In: Parry, M.L., O.F. Canziani, J.P. Palutikof, P.J. van der Linden \& C.E. Hanson (eds.). Climate Change 2007: Impacts, Adaptation and Vulnerability. Cambridge University Press, Cambridge, U.K.

Champion, H.G. \& S.K. Seth (1968). A Revised Survey of the Forest Types of India - 1st Edition. Govt. of India Press, Nueva Delhi, India.

Crick, H.Q.P. (2004). The impact of climate change on birds. Ibis 146: 48-56; http://dx.doi.org/10.1111/j.1474-919X.2004.00327.x

Crosby, M.J. (2005). Impacts of the Indian Ocean tsunami on birds and their habitats. Biodiversity 6(3): 14-19; http://dx.doi.org/ 10.1080/14888386.2005.9712770

Daniels, R., T. White \& K. Chapman (1993). Sea-level rise: destruction of threatened and endangered species habitat in South Carolina. Environmental Management 17: 373-385; http://dx.doi.org/ 10.1007/BF02394680

Dasgupta, S., B. Laplante, C. Meisner, D. Wheeler \& J. Yan (2007). The Impact of Sea Level Rise on Developing Countries: A Comparative Analysis. World Bank, Washington, D.C.

Dyurgerov, M.B. \& M.F. Meier (1997). Year-to-year fluctuations of global mass balance of small glaciers and their contribution to sealevel changes. Arctic and Alpine Research 29: 392-402.

Erasmus, B.F.N., A.S. van Jaarsveld, S.L. Chown, M. Kshatriya \& K.J. Wessels (2002). Vulnerability of South African animal taxa to 
climate change. Global Change Biology 8: 679-693; http://dx.doi. org/10.1046/j.1365-2486.2002.00502.x

Galbraith, H., R. Jones, R. Park, J. Clough, S. Herrod-Julius, B. Harrington \& G. Page (2002). Global climate change and sea level rise: Potential losses of intertidal habitat for shorebirds. Waterbirds 25: 173-183; http://dx.doi.org/10.1675/15244695(2002)025[0173:GCCASL]2.0.CO;2

Gopal, B. \& M. Chauhan (2006). Biodiversity and its conservation in the Sundarban mangrove ecosystem. Aquatic Sciences 68: 338-354; http://dx.doi.org/ 10.1007/s00027-006-0868-8

Hitz, S., \& J. Smith (2004). Estimating global impacts from climate change. Global Environmental Change-Human and Policy Dimensions 14: 201-218.

IPCC (2007). Climate Change 2007: The Physical Science Basis. Cambridge University Press, Cambridge.

Islam, M.Z. \& A.R. Rahmani (2004). Important Bird Areas in India Priority Sites for Conservation. Oxford University Press, BNHS, IBCN and BirdLife International (UK), 1200pp.

Islam, M.Z. \& A.R. Rahmani (2008). Existing and Potential RAMSAR Sites in India. Oxford University Press, BNHS, IBCN and BirdLife International (UK), 600pp.

IUCN \& UNEP-WCMC (2010). The World Database on Protected Areas (WDPA): Annual Release [On-line]. Cambridge, UK: UNEP-WCMC. Available at: www.wdpa.org [Accessed on 24 May 2010].

LaFever, D.H., R.R. Lopez, R.A. Feagin \& N.J. Silvy (2007). Predicting the impacts of future sea-level rise on an endangered lagomorph. Environmental Management 40: 430-437; http://dx.doi.org/ 10.1007/s00267-006-0204-z

Li, X., R.J. Rowley, J.C. Kostelnick, D. Braaten, J. Meisel \& K. Hulbutta (2009). GIS analysis of global inundation impacts from sea level rise. Photogrammetric Engineering and Remote Sensing 75: 807-818.

McKee, K.L., D.R. Cahoon \& I.C. Feller (2007). Caribbean mangroves adjust to rising sea level through biotic controls on change in soil elevation. Global Ecology and Biogeography 16: 545-556; http:// dx.doi.org/10.1111/j.1466-8238.2007.00317.x

Menon, S., J. Soberón, X. Li \& A.T. Peterson (2010). Preliminary globa assessment of terrestrial biodiversity consequences of sea-leve rise mediated by climate change. Biodiversity and Conservation 19: 1599-1609; http://dx.doi.org/10.1007/s10531-010-9790-4

Miller-Rushing, A.J. \& R.B. Primack (2008). Global warming and flowering times in Thoreau's Concord: a community perspective. Ecology 89: 332-341; http://dx.doi.org/10.1890/07-0068.1

Mimura, N. (1999). Vulnerability of island countries in the South Pacific to sea level rise and climate change. Climate Research 12: 137-143.

Moritz, C., J.L. Patton, C.J. Conroy, J.L. Parra, G.C. White \& S.R Beissinger (2008). Impact of a century of climate change on smallmammal communities in Yosemite National Park, USA. Science 322: 261-264; http://dx.doi.org/ 10.1126/science.1163428

Olson, D.M., E. Dinerstein, E.D. Wikramanayake, N.D. Burgess, G.V.N. Powell, E.C. Underwood, J.A. Amico, I. Itoua, H.E. Strand, J.C. Morrison, C.J. Loucks, T.F. Allnutt, T.H. Ricketts, Y. Kura, J.F. Lamoreux, W.W. Wettengel, P. Hedao \& K.R. Kassem (2001). Terrestrial ecoregions of the world: A new map of life on Earth. BioScience 51: 933-938; http://dx.doi.org/10.1641/00063568(2001)051[0933:TEOTWA]2.0.CO;2
Parmesan, C., N. Ryrholm, C. Stefanescu, J.K. Hill, C.D. Thomas, H. Descimon, B. Huntley, L. Kaila, J. Kullberg, T. Tammaru, J. Tennent, J.A. Thomas \& M. Warren (1999). Poleward shift of butterfly species' ranges associated with regional warming. Nature 399: 579-583; http://dx.doi.org/10.1038/21181

Parmesan, C. \& G. Yohe (2003). A globally coherent fingerprint of climate change impacts across natural systems. Nature 421: 37-42; http://dx.doi.org/10.1038/nature01286

Peterson, A.T., M.A. Ortega-Huerta, J. Bartley, V. Sánchez-Cordero, J. Sobeŕon, R. H. Buddemeier \& D.R.B. Stockwell (2002). Future projections for Mexican faunas underglobal climate change scenarios. Nature 416: 626-629; http://dx.doi.org/10.1038/416626a

Peterson, A.T., H. Tian, E. Martínez-Meyer, J. Soberón, V. SánchezCordero \& B. Huntley (2005). Modeling distributional shifts of individual species and biomes, pp. 211-228. In: Lovejoy, T.E. \& L. Hannah (eds.). Climate Change and Biodiversity. Yale University Press, New Haven.

Rignot, E. \& P. Kanagaratnam (2006). Changes in the velocity structure of the Greenland Ice Sheet. Science 311: 986-990; http://dx.doi. org/10.1126/science.1121381

Rodgers, W.A. \& H.S. Panwar (1988). Planning a Wildlife Protected Area Network in India - 2 Volumes. Wildlife Institute of India, Dehra Dun.

Rodgers, W.A., H.S. Panwar \& V.B. Mathur (2000). Wildlife Protected Area Network in India: A Review (Executive Summary). Wildlife Institute of India. Dehradun, India.

Thomas, C.D., A. Cameron, R.E. Green, M. Bakkenes, L.J. Beaumont, Y.C. Collingham, B.F.N. Erasmus, M. Ferreira de Siqueira, A. Grainger, L. Hannah, L. Hughes, B. Huntley, A.S. Van Jaarsveld, G.E. Midgely, L. Miles, M.A. Ortega-Huerta, A.T. Peterson, O.L. Phillips \& S.E. Williams (2004a). Extinction risk from climate change. Nature 427: 145-148; http://dx.doi.org/10.1038/nature02121

Thomas, R., E. Rignot, G. Casassa, P. Kanagaratnam, C. Acuna, T. Akins, H. Brecher, E. Frederick, P. Gogineni, W. Krabill, S. Manizade, H. Ramamoorthy, A. Rivera, R. Russell, J. Sonntag, R. Swift, J. Yungel \& J. Zwally (2004b). Accelerated sea-level rise from West Antarctica. Science 306: 255-258; http://dx.doi.org/10.1126/science.1099650

Tingley, M.W., W.B. Monahan, S.R. Beissinger \& C. Moritz (2009). Birds track their Grinnellian niche through a century of climate change. Proceedings of the National Academy of Sciences USA 106: 19637-19643; http://dx.doi.org/10.1073/pnas.0901562106

Titus, J.G. (1990). Effect of climate change on sea-level rise and the implications for world agriculture. Hortscience 25: 1567-1572.

Visser, M.E., A.J. van Noordwijk, J.M. Tinbergen \& C.M. Lessells (1998). Warmer springs lead to mistimed reproduction in Great Tits (Parus major). Proceedings of the Royal Society B 265: 1867-1870; http://dx.doi.org/10.1098/rspb.1998.0514

Vitasse, Y., A. Porté, A. Kremer, R. Michalet \& S. Delzon (2009). Responses of canopy duration to temperature changes in four temperate tree species: Relative contributions of spring and autumn leaf phenology. Oecologia 161: 187-198; http://dx.doi.org/ 10.1007/s00442-009-1363-4

Weller, G.A. \& P.A. Anderson (eds.) (1998). Implications of Global Change in Alaska and the Bering Sea Region. Proceedings of a Workshop, 3-5 June 1997. Center for Global Change and Arctic System Research, University of Alaska, Fairbanks. 